Provided for non-commercial research and education use. Not for reproduction, distribution or commercial use.

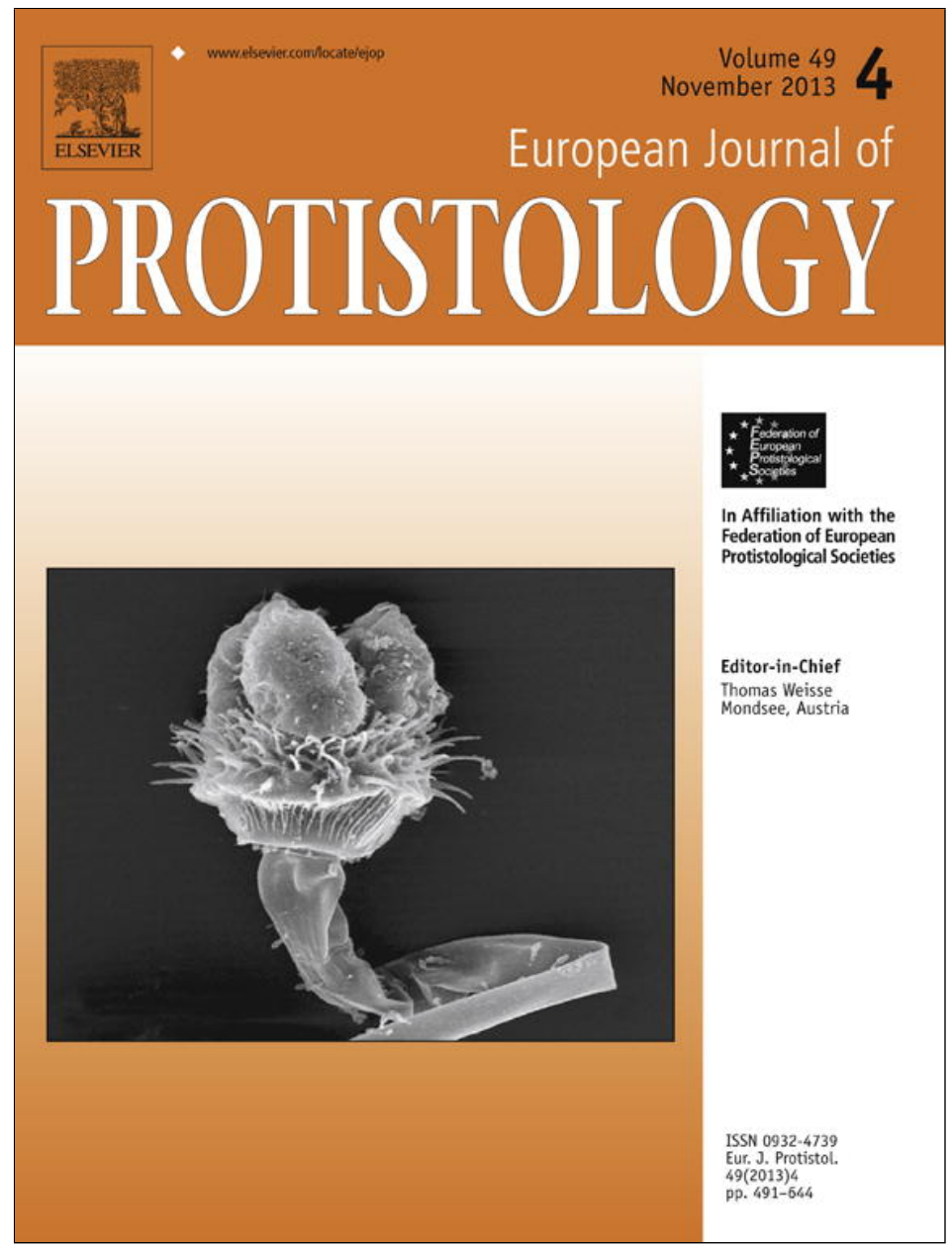

This article appeared in a journal published by Elsevier. The attached copy is furnished to the author for internal non-commercial research and education use, including for instruction at the authors institution and sharing with colleagues.

Other uses, including reproduction and distribution, or selling or licensing copies, or posting to personal, institutional or third party websites are prohibited.

In most cases authors are permitted to post their version of the article (e.g. in Word or Tex form) to their personal website or institutional repository. Authors requiring further information regarding Elsevier's archiving and manuscript policies are encouraged to visit:

http://www.elsevier.com/authorsrights 


\title{
Planktonic ciliate community structure in shallow lakes of lowland Western Europe
}

\author{
Jeroen Van Wichelen ${ }^{\mathrm{a}, *}$, Liselotte S. Johansson ${ }^{\mathrm{b}}$, Pieter Vanormelingen ${ }^{\mathrm{a}}$, Steven A.J. Declerck ${ }^{\mathrm{d}}$, \\ Torben L. Lauridsen ${ }^{\mathrm{b}}$, Luc De Meester ${ }^{\mathrm{c}}$, Erik Jeppesen ${ }^{\mathrm{b}}$, Wim Vyverman ${ }^{\mathrm{a}}$ \\ ${ }^{a}$ Laboratory of Protistology and Aquatic Ecology, Ghent University, Krijgslaan 281 (S8), 9000 Gent, Belgium \\ ${ }^{\mathrm{b}}$ Department of Bioscience, Aarhus University, Vejlsфvej 25, 8600 Silkeborg, Denmark \\ ${ }^{\mathrm{c}}$ Laboratory of Aquatic Ecology, Catholic University of Leuven, Ch. De Bériotstraat 32, 3000 Leuven, Belgium \\ ${ }^{\mathrm{d}}$ Department of Aquatic Ecology, Netherlands Institute of Ecology (NIOO-KNAW), Postbus 50, 6700 AB Wageningen, Netherlands
}

Received 27 February 2013; received in revised form 5 June 2013; accepted 17 June 2013

Available online 23 July 2013

\begin{abstract}
Temperate shallow meso- to eutrophic lakes can exist in one of two alternative states with contrasting foodwebs, referred to as the clear-water and the turbid state. We describe the planktonic ciliate communities of such lakes based on a survey of 66 northwestern European lakes. Ciliates were enumerated and identified to species level according to the quantitative protargol staining technique. Ciliate biomass was on average twice as high in the turbid than in the clear-water lakes. The ciliate communities were dominated by oligotrichs and protostomatids, and no differences in functional composition or $\alpha$-diversity could be detected between turbid and clear-water lakes, although $\beta$-diversity tended to be higher in the latter. At the species level, however, community structure strongly differed between turbid and clear-water lakes, and several indicator species could be identified for the different lake categories. Variation partitioning showed that nutrient status did not explain ciliate community structure independent of the alternative states, while lake area was identified as an additional structuring factor for the ciliate communities. These results stress the importance of the ecosystem structure in shaping ciliate communities in temperate shallow lakes and suggest that nutrient status has little direct effect on ciliate community structure in such lakes.
\end{abstract}

(C) 2013 Elsevier GmbH. All rights reserved.

Keywords: Community structure; Indicator species; Lowland Europe; Planktonic ciliates; Shallow lakes; Stable states

\section{Introduction}

Temperate meso- to eutrophic shallow lakes can essentially exist in one of two alternative states where primary production may be either dominated by submerged macrophytes (the clear-water state) or by phytoplankton (the turbid state) (Jeppesen et al. 1998; Moss 1990; Scheffer et al. 1993). Both states are stabilized by a suite of positive feedback mechanisms. At lower nutrient levels, a luxuriant submerged

\footnotetext{
*Corresponding author. Tel.: +3209264 85 05; fax: +32 092648599 .

E-mail address: jeroen.vanwichelen@UGent.be (J. Van Wichelen).
}

macrophyte vegetation maintains suitable light conditions for its own growth by preventing wind resuspension of the sediment, by limiting the development of phytoplankton by nutrient uptake and the production of allelopathic substances, and by providing shelter to piscivorous fish and large-bodied zooplankton, the latter being efficient phytoplankton grazers. At the highest nutrient levels, the high turbidity caused by the increased phytoplankton biomass impairs submerged macrophyte development through light limitation. Turbidity is further enhanced by a reduced zooplankton grazing pressure due to the absence of protective vegetation for large-bodied zooplankton and less piscivorous fish, favoring benthivorous and zooplanktivorous fish and consequently 
smaller zooplankton, and by resuspension of the unprotected sediments. At intermediate nutrient levels both states are possible and disturbances, such as for example extreme weather conditions, lake drawdown or fish kills, may be needed to tip lakes from one state to the other.

These alternative stable states are important drivers of the biomass, diversity and community structure of the more 'classical' components of the aquatic food web, i.e. phytoplankton (e.g. Muylaert et al. 2010; Vanormelingen et al. 2008), zooplankton (e.g. Cottenie et al. 2001; Jeppesen et al. 2002) and fish (e.g. Van Wichelen et al. 2007). An increasing phytoplankton production along the trophic gradient also fuels the development of abundant communities of bacteria and a wide array of protozoa. These regenerate nutrients and function as an additional food source for higher trophic levels, a concept known as the microbial loop (Azam et al. 1983; Pomeroy 1974). Macrophytes can have a profound effect on the abundance and structure of microbial communities, mainly due to a stronger predation pressure by larger bodied zooplankton (Jeppesen et al. 2002; Jürgens and Jeppesen 1998). However, the importance of shallow lake status in structuring the species composition of these previously often overlooked components of the aquatic foodweb has so far only been demonstrated for bacterioplankton (Ng et al. 2010; Van der Gucht et al. 2005; Wu et al. 2007).

Ciliates are heterotrophic protists preying on a diverse array of microbial organisms (Callieri et al. 2002; Fyda et al. 2005; Müller and Schlegel 1999; Premke and Arndt 2000; Stabell 1996) and are themselves prey for zooplankton (Jack and Gilbert 1997; Marchessault and Mazumder 1997) and even fish larvae (Fukami et al. 1999). As such, they constitute an important link in freshwater planktonic food chains (Porter et al. 1979; Wickham and Gilbert 1993). Ciliate abundance generally increases with lake trophy (Beaver and Crisman 1982; Galbraith and Burns 2010; Hwang and Heath 1997; Mathes and Arndt 1994; Pfister et al. 2002) as does their importance relative to zooplankton (Auer et al. 2004; Mathes and Arndt 1994). In shallow eutrophic waters they often dominate the protozoan biomass and can exert a grazing pressure on the phyto- and bacterioplankton comparable to that of metazooplankton (Mathes and Arndt 1994, 1995; Zingel 1999). The relative importance of small $(<35 \mu \mathrm{m})$, mainly bacterivorous, ciliates tends to increase with increasing trophy (Beaver and Crisman 1982; Jürgens et al. 1999; Nakano et al. 1998). This is because under oligotrophic conditions, bacterial concentrations are restricted and larger ciliates capable of also ingesting small phytoplankton are believed to be less resource limited. Under eutrophic conditions, exploitive competition between algivorous ciliates and larger zooplankton in combination with the higher turn-over rates of smaller bacterivorous ciliates favor the latter (Beaver and Crisman 1982).

Apart from their functional role in the aquatic food web and its dependence on lake trophy, relatively little is known about the composition of the planktonic ciliate communities in shallow freshwater lakes. Most studies are limited to one or at most a few sites and are typically of poor taxonomical resolution (Foissner et al. 1999; Pfister et al. 2002). We studied the structure and diversity of planktonic ciliate communities in a set of 66 temperate meso- to hypertrophic shallow lakes of contrasting ecological state (turbid versus clear-water) in two regions in lowland Western Europe (Belgium/The Netherlands and Denmark). In each region, lakes were selected to represent independent gradients in total phosphorus (TP) content, coverage by submerged macrophytes, lake surface area and degree of connectedness (see Declerck et al. 2005). This sampling design allowed us to disentangle the effects of each of these normally correlated environmental gradients. We used this unique set of shallow lakes to (1) describe planktonic ciliate community structure in temperate eutrophic shallow lakes, (2) test whether the two alternative states harbor different ciliate communities in terms of total abundance, diversity and (functional) community composition, and (3) determine the relative importance of the alternative states in structuring ciliate communities as compared to nutrient status (TP) and lake area.

\section{Material and Methods}

\section{Sampling}

Sixty-six shallow, circum-neutral to alkaline, mesoto hypertrophic freshwater lakes located in Belgium/The Netherlands (34 lakes) and Denmark (32 lakes) were sampled (Table 1). During the summer season (May-October) of 2000 (41 lakes) and 2001 (25 lakes), depth integrated water samples were collected monthly on 8 (lakes $<5$ ha) or 16 ( $>5 \mathrm{ha}$ ) random locations within each lake. By using a tube sampler $(2 \mathrm{~m}$ length, volume $8.5 \mathrm{~L}$ ) the complete water layer on each location was sampled. However, on a few occasions (water depth $>2 \mathrm{~m}$ ) additional water samples with a depth interval of 1-2 $\mathrm{m}$ were taken with a bottle sampler (volume $5 \mathrm{~L}$ ). Care was taken to avoid contamination from the sediment or aquatic vegetation. From each sampled location, 3 (lakes $>5 \mathrm{ha}$ ) or $6 \mathrm{~L}$ ( $<5 \mathrm{ha}$ ) of water were pooled to yield one spatial integrated sample that was gently stirred prior to subsampling. A subsample of $300 \mathrm{~mL}$ for the analysis of ciliates was fixed with Bouin's fixative (5\% final concentration) according to Montagnes and Lynn (1993). A $50 \mathrm{~mL}$ subsample for analysis of bacteria, heterotrophic nanoflagellates (HNF) and ultra-phytoplankton $(<5 \mu \mathrm{m})$ including picocyanobacteria was fixed with $0.2-\mu \mathrm{m}$ filtered formalin ( $2 \%$ final concentration). A $100 \mathrm{~mL}$ subsample for phytoplankton analysis was fixed with acid Lugol's solution $(0.1 \%$ final concentration). Subsamples of 2 and $15 \mathrm{~L}$ were filtered over a net with mesh size 30 , respectively $64 \mu \mathrm{m}$, for the analysis of rotifers and crustacean zooplankton. Both $100 \mathrm{~mL}$ concentrates were fixed with Lugol's solution (4\% final concentration). An untreated $4 \mathrm{~L}$ subsample was gathered for the measurement of relevant physical and chemical parameters 
Table 1. List of selected variables measured in the lakes during the growing season (May-October) showing for each variable the average value, standard deviation and range for each lake category. Variables in bold were used for the cluster analysis to divide the lakes into different categories.

\begin{tabular}{|c|c|c|c|}
\hline Variable & Clear & Intermediate & Turbid \\
\hline Surface area (ha) & $26.6 \pm 43.3(0.40-170)$ & $10.3 \pm 20.9(0.20-91)$ & $18.9 \pm 27.4(0.70-109)$ \\
\hline Mean depth (m) & $1.34 \pm 0.87(0.51-3.63)$ & $1.14 \pm 0.50(0.60-2.70)$ & $1.36 \pm 0.75(0.50-3.50)$ \\
\hline Water temperature $\left({ }^{\circ} \mathrm{C}\right)$ & $16.4 \pm 1.5(13.3-18.9)$ & $17.3 \pm 2.3(13.5-22.8)$ & $17.7 \pm 2.1(14.0-21.3)$ \\
\hline $\mathrm{pH}$ & $8.06 \pm 0.55(6.96-9.35)$ & $7.79 \pm 0.50(6.49-8.69)$ & $7.92 \pm 0.46(6.85-8.67)$ \\
\hline Conductivity $\left(\mu \mathrm{S} \mathrm{cm}^{-1}\right)$ & $414 \pm 171(89-816)$ & $344 \pm 154(90-614)$ & $382 \pm 187(129-900)$ \\
\hline $\begin{array}{l}\text { Suspended particulate } \\
\text { matter }\left(\mathbf{m g ~ L}^{-\mathbf{1}}\right)^{* * *} \\
\left(\mathrm{C}<\mathrm{I}^{* * *}, \mathrm{C}<\mathrm{T}^{* * *}\right)\end{array}$ & $6.6 \pm 3.3(1.7-16.1)$ & $13.4 \pm 7.1(4.6-36.5)$ & $17.5 \pm 9.6(5.5-42.7)$ \\
\hline $\begin{array}{l}\text { Total phosphorus }\left(\mu \mathrm{gPL}^{-1}\right)^{*} \\
\qquad\left(\mathrm{C}<\mathrm{T}^{*}, \mathrm{I}<\mathrm{T}^{*}\right)\end{array}$ & $194 \pm 220(8-708)$ & $169 \pm 193(19-856)$ & $456 \pm 774(78-2991)$ \\
\hline Total nitrogen $\left(\mu \mathrm{g} \mathrm{N} \mathrm{L}^{-1}\right)$ & $1113 \pm 769(150-2800)$ & $1200 \pm 626(160-2640)$ & $1597 \pm 841(340-3680)$ \\
\hline $\begin{array}{l}\text { Submerged macrophytes } \\
(\% \text { coverage })^{* * * *}\left(C>I^{* *},\right. \\
\left.C>T^{* * * *}, I>T^{* * *}\right)\end{array}$ & $46 \pm 28(7-96)$ & $7 \pm 11(0.1-36)$ & $\mathbf{0}$ \\
\hline $\begin{array}{l}\text { Chlorophyll a }\left(\boldsymbol{\mu g} \mathbf{L}^{-1}\right)^{* * *} \\
\left(\mathrm{C}<\mathrm{I}^{* * * *}, \mathrm{C}<\mathrm{T}^{* * *}\right)\end{array}$ & $12 \pm 7(3-31)$ & $45 \pm 30(15-141)$ & $68 \pm 41(24-196)$ \\
\hline $\begin{array}{l}\text { Small phytoplankton (\% } \\
\text { phytoplankton biomass) }\end{array}$ & $23 \pm 24(2-84)$ & $18 \pm 13(0-43)$ & $19 \pm 25(0-94)$ \\
\hline 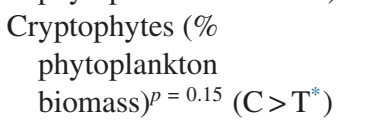 & $31 \pm 29(1-94)$ & $23 \pm 29(0-85)$ & $11 \pm 14(0-54)$ \\
\hline $\begin{array}{l}\text { Picocyanobacteria } \\
\qquad\left(10^{3} \text { ind } \mathrm{mL}^{-1}\right)^{* *}\left(\mathrm{C}<\mathrm{I}^{* *},\right. \\
\left.\mathrm{C}<\mathrm{T}^{*}\right)\end{array}$ & $118 \pm 433(0.433-2098)$ & $584 \pm 1523(1.345-6018)$ & $161 \pm 268(1.329-1235)$ \\
\hline Bacteria $\left(10^{6}\right.$ ind $\left.\mathrm{mL}^{-1}\right)$ & $3.57 \pm 1.76(0.82-7.71)$ & $4.46 \pm 2.20(1.85-9.34)$ & $4.61 \pm 2.48(1.42-10.63)$ \\
\hline $\begin{array}{l}\text { Heterotrophic nanoflagellates } \\
\quad\left(\text { ind } \mathrm{mL}^{-1} \text { ) }\right.\end{array}$ & $2140 \pm 1818(337-6347)$ & $3025 \pm 3640(300-13522)$ & $2659 \pm 1983(238-7853)$ \\
\hline $\begin{array}{l}\left.\text { Ciliates (ind } \mathrm{mL}^{-1}\right)^{* * * *} \\
\quad\left(\mathrm{C}<\mathrm{I}^{* *}, \mathrm{C}<\mathrm{T}^{* *}\right)\end{array}$ & $31 \pm 20(5-71)$ & $77 \pm 69(23-275)$ & $87 \pm 83(10-352)$ \\
\hline $\begin{array}{l}\text { Ciliates }\left(\mu \mathrm{gC} \mathrm{L}^{-1}\right)^{* * *}\left(\mathrm{C}<\mathrm{I}^{* *} \text {, }\right. \\
\left.\quad \mathrm{C}<\mathrm{T}^{* * *}\right)\end{array}$ & $56 \pm 73(7-355)$ & $128 \pm 121(25-532)$ & $112 \pm 81(14-308)$ \\
\hline $\begin{array}{l}\text { Ciliates ( } \% \\
\text { proto-metazooplankton } \\
\text { biomass) }\end{array}$ & $20 \pm 18(1-85)$ & $28 \pm 13(7-55)$ & $23 \pm 14(2-53)$ \\
\hline Rotifers $\left(\mu \mathrm{gC} \mathrm{L}^{-1}\right)^{*}$ & $68 \pm 78(0.2-283)$ & $116 \pm 95(13-325)$ & $124 \pm 120(17-412)$ \\
\hline $\begin{array}{l}\text { Calanoid copepods } \\
\qquad\left(\mu g \mathrm{~g} \mathrm{~L}^{-1}\right)\end{array}$ & $13 \pm 19(0-78)$ & $19 \pm 24(0-74)$ & $19 \pm 23(0-91)$ \\
\hline $\begin{array}{l}\text { Cyclopoid copepods } \\
\qquad\left(\mu g \mathrm{CL}^{-1}\right)^{*}\left(\mathrm{C}<\mathrm{T}^{*}\right)\end{array}$ & $26 \pm 22(0.1-78)$ & $44 \pm 44(0.1-177)$ & $70 \pm 89(2-402)$ \\
\hline Cladocerans $\left(\mu \mathrm{g} \mathrm{C} \mathrm{L}^{-1}\right)$ & $125 \pm 161(2-732)$ & $105 \pm 82(3-272)$ & $183 \pm 183(2-733)$ \\
\hline $\begin{array}{l}\text { Large daphnids (\% } \\
\text { metazooplankton } \\
\text { biomass) }\end{array}$ & $14 \pm 27(0-97)$ & $1 \pm 5(0-21)$ & $1 \pm 5(0-23)$ \\
\hline $\begin{array}{l}\text { Fish }\left(\mathrm{kg} \mathrm{net}^{-1}, \text { average }\right. \\
\text { littoral-pelagic) }\end{array}$ & $3.54 \pm 3.06(0-10.1)$ & $4.32 \pm 2.62(0-10.2)$ & $5.1 \pm 3.32(0-11.3)$ \\
\hline
\end{tabular}

The effect of lake type and significant differences between lake categories (C: clear-water, T: turbid and I: intermediate lakes) based on pairwise comparisons after Kruskall Wallis ANOVA are indicated with:

${ }^{*} p<0.05$.

${ }^{* * *} p<0.01$.

${ }^{* * * *} p<0.001$.

(suspended particulate matter, nutrients, and pigments) in the laboratory. All samples were kept cool in an icebox during the fieldwork and the transport for further analysis in the laboratory. On each sampling occasion, temperature, conductivity,
$\mathrm{pH}$ and Secchi disk depth were measured at a fixed location in the middle of the lake. Coverage by submerged macrophytes was assessed during mid-summer on point locations along transects covering the entire lake. Fish were 
sampled overnight with multiple gill nets in both littoral and pelagic areas. The catch of each fish species was divided into two size categories ( $<10$ and $\geq 10 \mathrm{~cm}$ ) and total biomass for each species estimated using length-weight relationships based on measurements of 50-100 individuals for each size category. For more details concerning the sampling procedures we refer to Declerck et al. (2005).

\section{Sample analysis}

The untreated $4 \mathrm{~L}$ samples were further processed in the laboratory upon arrival from the field. The chlorophyll a concentration was estimated spectrophotometrically $(665 / 750 \mathrm{~nm})$ after ethanol extraction (Jespersen and Christoffersen 1987). Suspended particulate matter (SPM) was determined gravimetrically by filtering a known volume of water through a pre-weighted glass fiber filter (Whatman $\mathrm{GF} / \mathrm{F})$. A $100-\mathrm{mL}$ unfiltered water sample was frozen at $20^{\circ} \mathrm{C}$ and the six monthly samples were combined afterwards into one composite sample for the analysis of TP and TN after persulphate digestion (Koroleff 1970; Solórzano and Sharp 1980) using a Skalar analytical auto-analyzer (Grasshoff 1976; Koroleff 1976). Within $24 \mathrm{~h}$ after sampling, $1-5 \mathrm{~mL}$ of formalin fixed water was filtered on black polycarbonate filters (Nuclepore, $0.2 \mu \mathrm{m}$ pore sizes), which were stained with DAPI, mounted on microscopic slides and stored at $-20^{\circ} \mathrm{C}$ for the enumeration (minimal 300 cells) of bacteria and picocyanobacteria using epifluorescence microscopy according to Hobbie et al. (1977) and MacIsaac and Stockner (1993). Accordingly, between 4 and $20 \mathrm{~mL}$ of the formalin fixed water and filters with $0.8 \mu \mathrm{m}$ pore sizes were used for the enumeration of HNF and eukaryotic ultra-phytoplankton using epifluorescence microscopy according to MacIsaac and Stockner (1993) and Sherr et al. (1993). To minimize potential decomposition, the fixed samples for phytoplankton, ciliates and zooplankton were stored at $4{ }^{\circ} \mathrm{C}$ in the dark until the end of the sampling season when the samples from the different months for each organism group were mixed at equal volumes ( $1 / 2$ of the volume of each monthly sample) to yield one composite spatial and temporal integrated sample for each lake. The relative contribution of different taxonomical (e.g. cryptophytes, cyanobacteria) or functional (size classes) phytoplankton groups was determined from cell counts of a minimum of 200 individuals using an inverted microscope (Utermöhl 1958). Biovolumes were calculated according to Hillebrand et al. (1999) and converted to carbon biomass using published carbon-volume regressions (Menden-Deuer and Lessard 2000). The population density of cladocerans and rotifers was determined by counting at least 300 individuals of each group, using a stereomicroscope. Cyclopoid copepods were counted until at least 20 adult females were encountered. The zooplankton densities were converted to dry mass using published length-weight regressions (Bottrell et al. 1976) and subsequently to carbon biomass, assuming that $48 \%$ of the dry weight consists of carbon (Andersen and Hessen 1991). In addition to these three major zooplankton groups, the relative contribution of large daphnids (Daphnia magna $+D$. pulex) to the total metazooplankton biomass was also selected as a potentially important structuring top-down variable for the ciliate communities.

\section{Ciliate enumeration and identification}

Between 10 (very turbid lakes) and $150 \mathrm{~mL}$ (very clear lakes) of the refrigerated Bouin's fixed composite samples were filtered on mixed cellulose esters filters (Millipore, $1.2 \mu \mathrm{m}$ pore sizes), embedded in agar, stained with protargol and permanently mounted on microscopic slides according to the quantitative protargol staining (QPS) technique (Montagnes and Lynn 1993; Pfister et al. 1999; Skibbe 1994) within one month after the last sampling. Each slide was scanned at $10 \times 100$ magnification along vertical transects using a Leitz Diaplan or a Leica DMLB microscope with differential interference contrast illumination for the identification and enumeration of at least 200 specimens and subsequent calculation of the ciliate densities. For each species, wherever possible, the dimensions of at least five individuals in each sample were measured. Using the average dimensions calculated from all samples, a biovolume was calculated for each species using simple geometric shapes (e.g. sphere, ellipsoid) and taking into account a shrinkage of $60 \%$ due to fixatives and the QPS method (Jerome et al. 1993). The ciliate densities were transformed to carbon biomass using

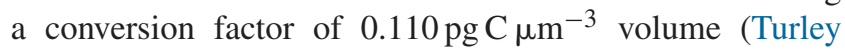
et al. 1986). Species identification was based on Foissner et al. (1991, 1992, 1994,1995, 1999) and Kahl (1935). Some common, morphological similar species were difficult to distinguish in the majority of samples due to poor preservation and/or staining of these species, although in several samples the staining was of enough quality to easily differentiate them (see footnotes in Supplementary Table 1). These problematic species were combined into groups prior to data analysis as was the case for several small Urotricha spp. (U. agilis, U. globosa, U. farcta) that were combined in a group 'small urotrichs'.

\section{Statistical analyses}

Ciliate communities from both geographically distinct regions (Belgium/The Netherlands - Denmark) were analyzed together. There were no significant differences in total biomass between regions (Mann-Whitney $U$ test, $p=0.748$ ) and functional or species composition was broadly similar, as there were no significant differences in sample scores for the first two axes of a principal components analysis of the species or functional group composition (PCA, Mann-Whitney $U$-tests, $p>0.5$ ). However, the regions were separated along the third axis of the species composition PCA $(p=0.026)$, pointing at a moderate region effect. 
Ciliate species were assigned to functional groups based on taxonomy (main ciliate orders following, Foissner et al. 1991, 1992, 1994, 1995), size (small:<20, medium: 20-40, large: $40-80$, very large: $>80 \mu \mathrm{m}$ in greatest axial linear dimension), food preference (algivorous, bacterivorous, predatory, omnivorous, mixotrophic) and preferred habitat (eupelagic versus littoral, benthic or macrophyte associated taxa), all based on Foissner et al. (1999) (see Supplementary Table 1).

Diversity calculations (SR: species richness; SI: Shannon diversity index; PI: Pielou's evenness index) were carried out in PRIMER 5. For the estimation of SR for each lake, we applied rarefaction with a cut-off level of 200 counted individuals. Species richness was also partitioned into its $\alpha$ (local diversity) and $\beta$ (inter-lake variability) components using PARTITION 3.0 (Veech and Crist 2009). We selected a balanced sampling design without sample weighting and an individual-based randomization method (1000 randomizations).

Variation in ciliate community structure was visualized using principal component analysis (PCA) based on square root transformed relative biomass data carried out in CANOCO 4.5 (ter Braak and Šmilauer 1998). Biomass was preferred over densities because of the large size differences between ciliate species (see Supplementary Table 1). Species only present in a single lake and species of which less than 10 individuals were counted in both regions (corresponding to $0.1 \%$ of the total amount of counted specimens of all lakes in each region) were omitted from the data set. Based on these criteria, 60 species were retained for analysis, representing an average of $82 \%$ of the total ciliate biomass in a lake (see Supplementary Table 1). In 7 lakes, the remaining ciliate biomass represented less than $50 \%$ of total ciliate biomass because the omitted species were very large ciliates (inter alia Paradileptus elephantinus, Stentor amethystinus, Linostomella vorticella, Spirostomum minus, Frontonia atra). Before performing the PCA, the linearity of the species response curves was checked by a detrended correspondence analysis for which the gradient lengths of the first two axes were below a threshold value of 3.0 (Lepš and Šmilauer 2003). A PCA based on the functional group composition was executed in the same way.

To evaluate differences between the ciliate communities of clear-water and turbid lakes, lakes were assigned to each state by group averaging clustering in PRIMER 5 (Clarke and Gorley 2001) on the base of a Euclidian distance similarity matrix of standardized data of three key variables in the stable states theory: macrophyte cover, suspended particulate matter (SPM) content and chlorophyll a concentration. The analysis was done on logarithmic (chl a, SPM) and fourth root (\% cover) transformed data to minimize deviations from normality. The significance of differences between the different lake categories was tested using Kruskall Wallis ANOVA followed by a pairwise comparison of the mean ranks in Statistica 7 for the following ciliate community variables: total biomass, contribution of eupelagic species, ciliate contribution to the total proto- and metazoan grazer biomass, relative abundance of the various functional groups, local diversity and sample scores on the first two axes of the species and functional group composition PCAs. Nonparametric testing was applied since several significant deviations from normality were observed according to the Shapiro-Wilk $W$ test. To test for effects of the alternative stable states on overall ciliate species or functional composition, redundancy analyses (RDA) were performed with the three stable-state related variables used for the cluster analysis as explanatory variables.

Indicator species for the different lake categories were suggested on the base of an Indicator Species Analysis following Dufrene and Legendre (1997) carried out in PCORD 5 (McCune and Mefford 1999). Based on their relative biomass and frequency, species were given an indicator value for each lake category between 0 (no indication) and 100 (perfect indication). This analysis was undertaken on relative biomass data of the same 60 species that were selected for the multivariate analysis.

A variation partitioning approach (Borcard et al. 1992; Peres-Neto et al. 2006) was used to assess the importance of the alternative stable states (macrophyte cover, SPM, and chlorophyll a concentration) for structuring ciliate communities relative to other (potentially) important environmental gradients, such as nutrient status (total phosphorus) and lake area. Variation partitioning of the species $(n=60)$ data was carried out using (partial) redundancy analyses in CANOCO4.5. Normality of the environmental variables was checked visually using histograms and deviations from normality were tested with the Shapiro-Wilk $W$ test in Statistica7. To minimize deviations from normality, macrophyte cover was fourth root and the other variables $\log _{10}(x+1)$ transformed. $R_{\text {adj }}^{2}$ values, which are independent of the number of environmental variables included, were calculated for the different fractions (Peres-Neto et al. 2006). To account for possible regional effects, permutation testing was done for each region separately using the 'blocks defined by covariables' option in CANOCO 4.5 (Lepš and Šmilauer 2003). Lake area was included because a preliminary forward selection redundancy analysis following Blanchet et al. (2008) using water temperature, conductivity, $\mathrm{pH}, \mathrm{TN}, \mathrm{TP}$, surface area, bacterial densities, heterotrophic nanoflagellate densities, picocyanobacterial densities, relative biomass contribution of small $(<20 \mu \mathrm{m})$ phytoplankton, relative biomass contribution of cryptophytes, total zooplankton biomass, total cladoceran biomass, cyclopoid copepod biomass, rotifer biomass and relative zooplankton biomass contribution of large daphnids as explanatory variables and chlorophyll a, SPM and submerged macrophyte cover as covariables identified it as an important variable in explaining ciliate community structure $\left(R_{\text {adj }}^{2}=\right.$ $2.9 \%, p<0.0001)$, together with cyclopoid copepods $\left(R_{\mathrm{adj}}^{2}=\right.$ $2.0 \%, p=0.0006)$ and picocyanobacteria $\left(R_{\mathrm{adj}}^{2}=1.0 \%\right.$, $p=0.0113)$. 


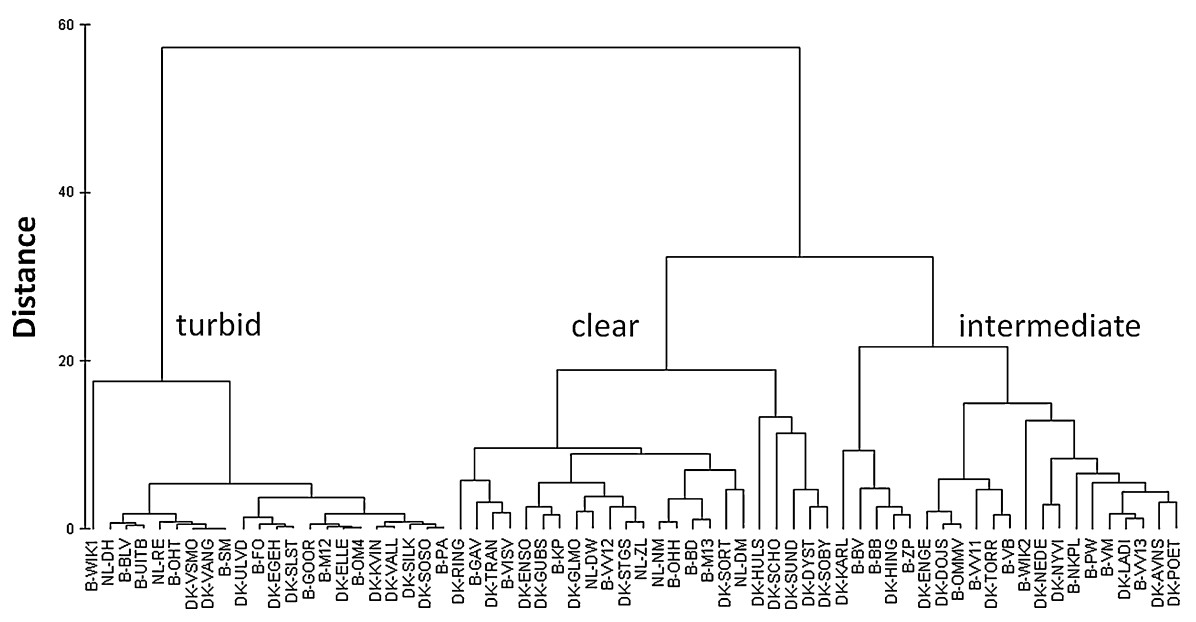

Fig. 1. Group averaging cluster diagram of 66 shallow European lowland lakes based on a Euclidian distance similarity matrix of standardized data on macrophyte cover, suspended particulate matter content and chlorophyll a concentration. DK: Denmark, NL: The Netherlands, B: Belgium.

\section{Results}

\section{Lake grouping}

Clustering on the base of submerged macrophyte cover, suspended matter content and chlorophyll a concentration divided the lakes into three categories: turbid, clear-water and intermediate (Fig. 1). Each of these categories contained lakes from both regions. The turbid lakes were mainly differentiated from the other lake types by the total absence of submerged macrophytes (Table 1). Intermediate lakes still maintained sparse vegetation in spite of a relative high amount of suspended matter (including phytoplankton).

\section{Ciliate communities}

Total ciliate densities varied between 5 and 352 ind $\mathrm{mL}^{-1}$ (median 47) and biomass between 7 and $532 \mu \mathrm{g} \mathrm{CL}^{-1}$ (median 57) (Table 1, Supplementary Table 1). In total, 168 ciliate taxa were determined of which the majority ( $72 \%)$ were identified to species level, $15 \%$ to genus level, and $13 \%$ to a higher taxonomical level. The majority belonged to gymnostomatids (32 taxa), peritrichs (30), prostomatids (22), hymenostomatids (19), oligotrichs, and hypotrichs (both 18) (Supplementary Table 1). Other ciliate orders were represented by less than 6 species each. Oligotrichs were the single most dominant ciliate group, representing on average $57 \%$ of the total biomass, followed by prostomatids (14\%). The estimated species richness in the lakes varied from 8 to 34 species with an average of $21 \pm 5$. Eupelagic species accounted for almost half of the total number of species and had an average biomass contribution of $87 \%$. In terms of feeding strategy, the ciliate communities were dominated by algivorous, bacterivorous, and mixotrophic ciliates, having biomass contributions of 39,18 , and $31 \%$, respectively. Omnivorous and predatory (preying on other ciliates) species had only a limited contribution.

Very common species, encountered in more than $70 \%$ of the sampled lakes, were all eupelagic and included oligotrichs like Pelagohalteria cirrifera (Fig. 2a, b), Pelagostrombidium mirabile (Fig. 2h) and Rimostrombidium brachykinetum (Fig. 2d), prostomatids like Balanion planctonicum (Fig. 2k) and Urotricha furcata (Fig. 2m) and the scuticociliate Cyclidium cf. heptatrichum (Fig. 2ab, ac). The main variation in the ciliate communities is shown using a biplot of the first two axes of a species composition PCA (Fig. 3B), representing 13.8 respectively $12.7 \%$ of the total community variation. The third and fourth axis represented 9.8 respectively $7.1 \%$ of the total variation.

\section{Influence of lake status}

Ciliate density and biomass were significantly lower in clear-water lakes than in turbid and intermediate lakes (Fig. 4a, b, Table 1). No significant differences could be found between the lake categories for the relative contribution of ciliates to total grazer biomass, the relative contribution of eupelagic species, the larger taxonomic groups, feeding strategies, size structure, or $\alpha$-diversity (Fig. $4 \mathrm{c}-\mathrm{h}$ ). Betadiversity tended to be higher in clear-water lakes than in turbid and intermediate lakes, but the difference diminished markedly when only the eupelagic taxa were taken into account (Fig. 4h).

An RDA with the three stable-state related variables as explanatory parameters for ciliate species composition was highly significant $\left(R_{\mathrm{adj}}^{2}=4.8 \%, p<0.0001\right)$. In the PCA of the species composition (Fig. 3A), clear-water lakes had significantly lower sample scores than the turbid lakes on the first 


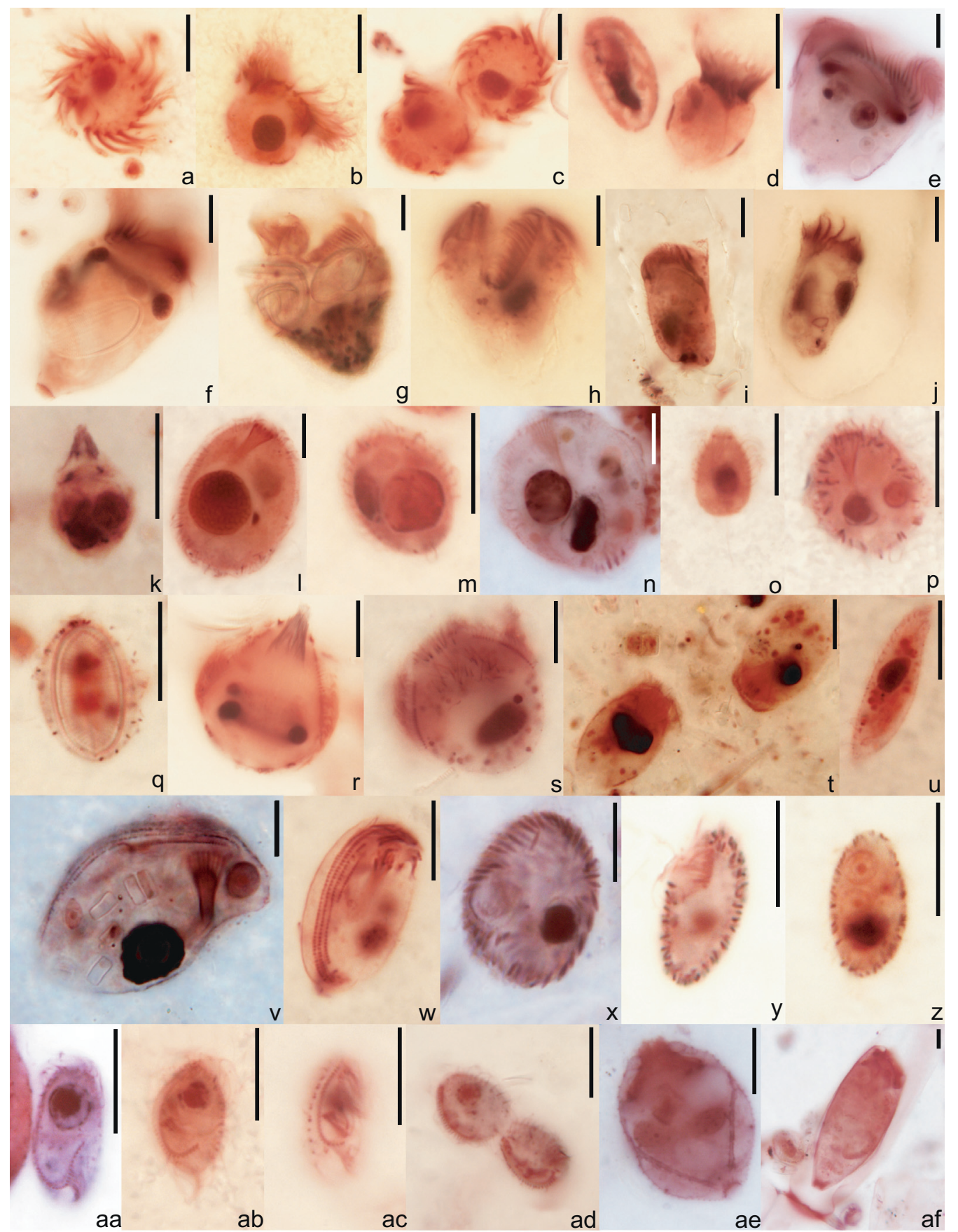

Fig. 2. Overview of microscopical pictures of dominant and some hitherto unidentified pelagic ciliates from shallow lowland lakes in Western Europe. Ciliates were mounted on permanent slides and stained with QPS. (a) and (b) Pelagohalteria cirrifera, (c) Pelagohalteria viridis, (d) Rimostrombidium brachykinetum, (e) Rimostrombidium lacustris, (f) Strobilidium caudatum (with captured pennate diatom inside, (g) Limnostrombidium viride with captured pennate diatoms), (h) Pelagostrombidium mirabile, (i) Tintinnopsis cylindrata, (j) Codonella cratera, (k) Balanion planctonicum, (1) Urotricha castalia, (m) Urotricha furcata, (n) Urotricha apsheronica/pelagica, (o) Urotricha agilis, (p) and (q) Urotricha sp. (with captured pennate diatom in (q)), (r) Askenasia acrostomia, (s) Askenasia chlorelligera, (t) an unidentified species, cf. Balantidion, (u) Litonotus alpestris, (v) Phascolodon vorticella (with captured food - mainly centric diatoms - inside), (w) Trochilia minuta, (x) Cinetochilum margaritaceum, (y) Cyrtolophosis mucicola, (z) Cyrtolophosis sp. (note the presence of zoochlorellae), (aa) Cyclidium plouneouri, (ab) and (ac) Cyclidium cf. heptatrichum, (ad) Cyclidium sp. 1 (deviding specimen), (ae) Vorticella aquadulcis (the stalk is not visible), (af) Vaginicola ampulla. All pictures were taken with an Olympus DP50 digital camera mounted on a Leitz Diaplan light microscope. Scale bar equals $10 \mu \mathrm{m}$. 
A

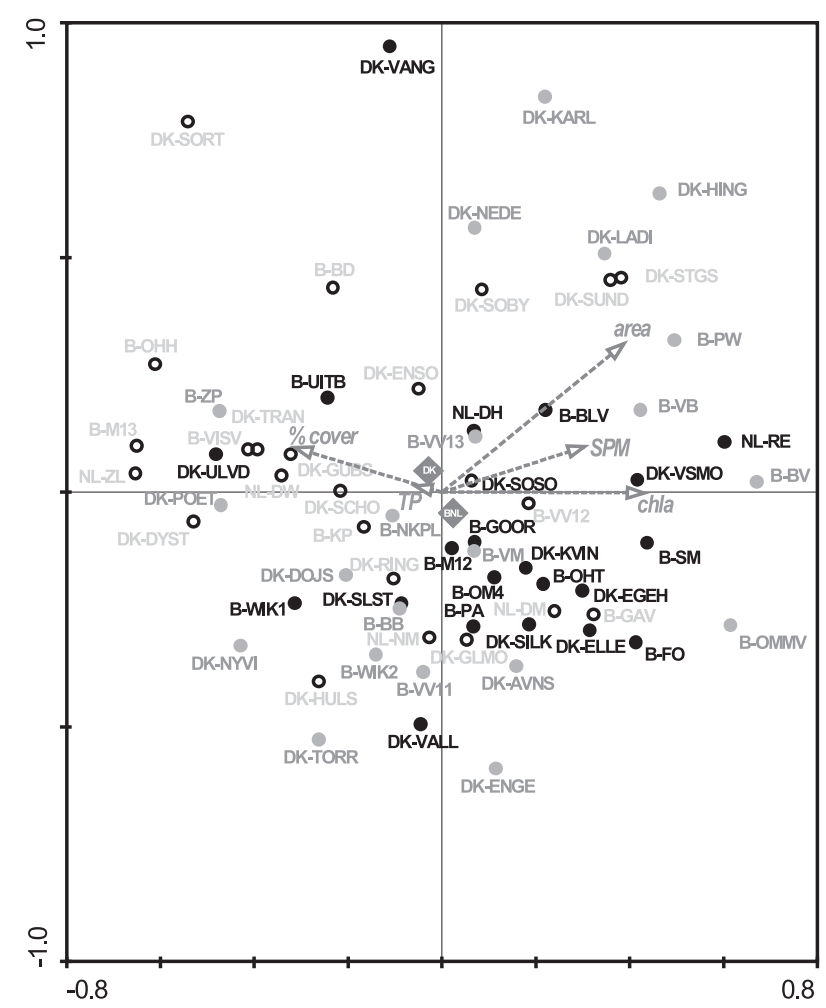

B

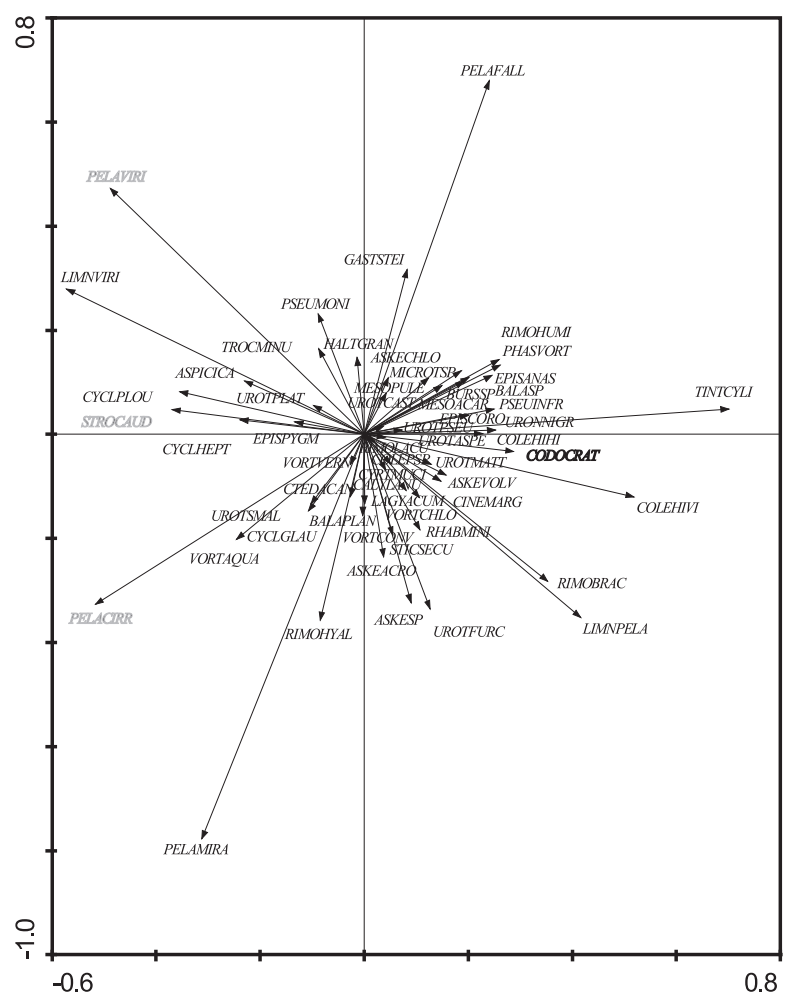

Fig. 3. Ordination diagrams of the first two axes of a principal component analysis (PCA) of ciliate species composition in 66 shallow European lowland lakes. (A) Biplot of sample scores, with lakes assigned to the clear-water (open circles), intermediate (gray circles) or the turbid state (solid circles) based on a cluster analysis constructed with lake macrophyte cover (\%cover), chlorophyll a (chla) and suspended particulate matter (SPM) concentration. These are here added as supplementary variables together with two other potentially important parameters, lake area (AREA) and nutrient load (TP). Gray diamonds represent the centroids for both geographical areas, Denmark (DK) and Belgium/The Netherlands (BNL). (B) Diagram of the same PCA with the ciliate species scores. Bold black and gray names represent indicator species for turbid and clear-water lakes, respectively. For full species names we refer to Supplementary Table 1.

axis (pairwise comparison after Kruskal-Wallis ANOVA, $p=0.021)$, but not on the second $(p=0.42)$. The sample scores of the intermediate lakes did not differ significantly from the other lake categories. In contrast, an RDA with the three stable state-related variables as explanatory parameters for the functional composition was not significant $\left(R_{\mathrm{adj}}^{2}=1.8 \%\right.$, $p=0.0816$ ), and the sample scores of the clear-water and turbid lakes did not differ along the first two axes of the functional group PCA (Kruskal-Wallis ANOVA, $p=0.66$ for axis $1, p=0.56$ for axis 2). Indicator Species Analysis revealed 3 ciliate species with a significant indicator value for clear-water lakes (Pelagohalteria viridis, $P$. cirrifera and Strobilidium caudatum) and 1 (Codonella cratera) for turbid lakes (Table 2).

Table 2. Results of Indicator Species Analysis for a selection of ciliates (species present in only 1 lake and species on which a total of less than 10 individuals were obtained in each region were omitted). The species is most characteristic for a specific lake category where its indicator value is highest (bold values). Only shown are significant indicator values as a percentage of perfect indication based on relative abundance (biomass) and frequency.

\begin{tabular}{llccrr}
\hline Taxon & Acronym & Clear & Intermediate & Turbid & $p$-Value \\
\hline Cyrtolophosis mucicola & CYRTMUCI & 0 & $\mathbf{2 6}$ & 2 & 0.0118 \\
Codonella cratera & CODOCRAT & 0 & 16 & $\mathbf{3 4}$ & 0.0144 \\
Pelagohalteria cirrifera & PELACIRR & $\mathbf{4 8}$ & 14 & 29 & 0.0224 \\
Pelagohalteria viridis & PELAVIRI & $\mathbf{4 9}$ & 8 & 17 & 0.0092 \\
Strobilidium caudatum & STROCAUD & $\mathbf{2 2}$ & 0 & 0 & 0.0096 \\
Coleps hirtus viridis & COLEHIVI & 1 & 16 & $\mathbf{3 4}$ & 0.0512 \\
Urotricha apsheronica/pelagica & UROTASPE & 3 & $\mathbf{2 7}$ & 1 & 0.0170 \\
\hline
\end{tabular}

\footnotetext{
*Only marginally significant.
} 

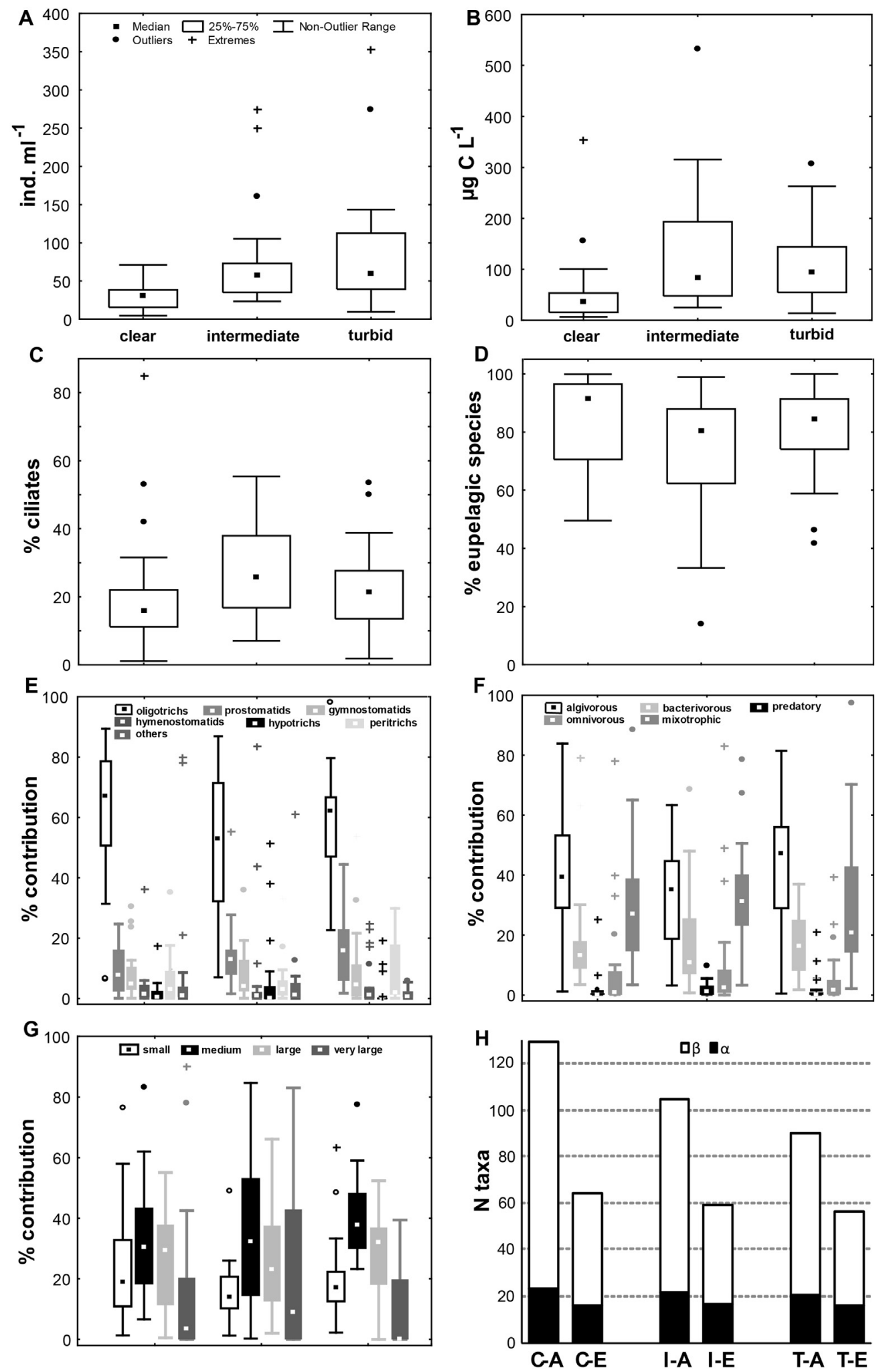

Fig. 4. Boxplots of ciliate density (a), biomass (b), contribution to total proto- and metazoan biomass (c), relative abundance of eupelagic species (d), major ciliate orders (e), different feeding types (f), different size classes (g), and $\alpha$ and $\beta$ diversity (h) - with C: clear-water, I: intermediate, T: turbid lakes, A: all species included, E: only eupelagic species included - for the different lake categories. No significant differences between lake categories were observed except for a significantly lower ciliate density and biomass in the clear-water lakes in comparison with the other lake types (Kruskal-Wallis ANOVA, $p<0.01$ ). 


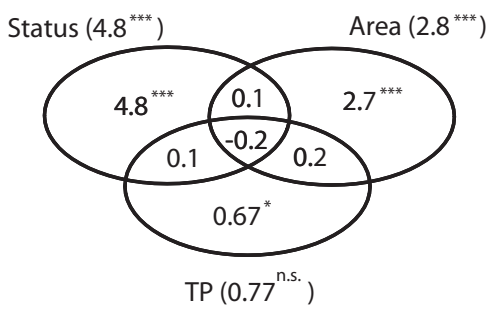

Fig. 5. Results of a variation partitioning analysis on the relative importance of the alternative stable states (based on chl a, SPM, $\%$ cover), lake area and nutrient status (TP) for ciliate species composition. Shown are $R_{\text {adj }}^{2}$ values expressed as percentage variation explained by the different categories with their significance $(* p<0.5, * * * p<0.001)$ and their overlap.

\section{Relative importance of stable states, nutrient status, and lake area}

Variation partitioning of the ciliate species composition revealed that the variation purely attributable to lake status was about twice as large as the variation explained by lake area alone $\left(R_{\text {adj }}^{2}=4.8\right.$ resp. $\left.2.7 \%\right)$. Nutrient status (TP) explained only a very limited and insignificant fraction of ciliate community turn-over (0.77\%, Fig. 5).

\section{Discussion}

In the investigated lakes, oligotrich and prostomatid ciliates together represented on average more than $75 \%$ of the total ciliate biomass. Dominance by oligotrich and protostomatid ciliates is observed in the pelagic of freshwater lakes worldwide (Galbraith and Burns 2010; Mathes and Arndt 1995; Mayer et al. 1997; Salbrechter and Arndt 1994; Zingel 1999) and classified by Foissner et al. (1991) as Oligotrichetea. Some authors have stated that dominance by oligotrichs is mainly characteristic for oligo-mesotrophic lakes with a low organic matter concentration (Beaver and Crisman 1982; Beaver et al. 1988; Carrias et al. 1998; Zingel et al. 2002). Here, this community dominated irrespective of nutrient status and state. This is in agreement with Mathes and Arndt (1994) who could not find a significant decrease in the relative contribution of oligotrichs with increasing trophy in 19 lakes in Northern Germany.

Our clustering procedure based on chlorophyll a, suspended matter and submerged macrophyte coverage grouped lakes into a turbid and a clear-water category, but it also revealed the existence of a third lake type with an intermediate position. We consider these intermediate lakes as rather unstable and on the brink of a shift toward one of both stable states (see Scheffer et al. 2001) and they therefore will be no further discussed here.

A frequently reported feature of ciliate communities in freshwater lakes is the biomass increase with lake trophy (Beaver and Crisman 1982; Galbraith and Burns 2010; Hwang and Heath 1997; Mathes and Arndt 1994;
Laybourn-Parry and Rogerson 1993; Pfister et al. 2002). Our study shows that at least for shallow lakes, this is dependent on the stable state and the accompanying aquatic food web structure. Planktonic ciliate biomass in the turbid lakes was, on average, much higher than in the clear-water lakes and this was independent of the nutrient status. This is in accordance to the higher biomass of other planktonic microbial organisms such as phytoplankton and bacterioplankton (e.g. Muylaert et al. 2004; Peretyatko et al. 2007) and can therefore be explained by higher food availability for planktonic ciliates in turbid lakes (Song 2000). In addition, stronger zooplankton predation may be responsible for a lower ciliate biomass in the clear-water lakes. We found a higher contribution of large daphnids to the zooplankton community in the clear-water lakes of our study (see Table 1). Daphnia, a keystone grazer in many planktonic systems, is able to exert a strong grazing pressure on all components of the microbial food web, also leading to stronger cascading effects down the food chain in clear, macrophyte-rich waters (Jeppesen et al. 2002; Jürgens 1994; Jürgens and Jeppesen 1998).

Surprisingly, the differences in food web structure between the two stable states did not result in clear differences in terms of ciliate feeding strategy, size structure, $\alpha$-diversity, and contribution of the large taxonomic groups between turbid and clear-water lakes. There was also no significant effect of stable state when traits were combined and functional composition was analyzed. This is especially surprising for size structure given that it is well-known that size-selective feeding by crustacean zooplankton can influence the size structure of ciliate communities (e.g. Agasild et al. 2013; Jack and Gilbert 1993; Wiackowski et al. 1994; Wickham 1995; Wickham and Gilbert 1991). Other, unknown, functional traits might therefore be important. A high growth rate can be one such factor, grazing resistance or avoidance another. Pelagohalteria viridis, a dominant species in our clear-water lakes, exhibits a jumping response which might reduce captivity by Daphnia (Jürgens 1994). Grazing by large daphnids in these lakes can potentially cause strong dominance by such grazing-resistant ciliate species. Also ciliate feeding strategies did not differ between clear-water and turbid lakes. Algivorous, mixotrophic, and bacterivorous ciliates were dominant irrespective of lake status, which seems to be a general feature of many planktonic ciliate communities (Foissner et al. 1999). The lack of differences in functional composition of the ciliate communities between the two stable states might also be partly attributed to our use of time-integrated water samples. Many temperate lakes possess an apparent seasonality in their protozoan communities with larger, preferable algivorous species dominating in spring and smaller species with more diverse food preferences during summer (Mathes \& Arndt 1994; Zingel and Nõges 2010). There are indications that this seasonality in functional composition can differ between turbid and clearwater shallow lakes (e.g. Song 2000; Zingel and Nõges 2008) and using pooled samples covering the spring and summer period could have obscured these differences in our study. 
Although ciliate $\alpha$-diversity was not significantly different between the lake categories, the clear-water and intermediate lakes had a higher $\beta$-diversity, which was mainly attributable to macrophyte-associated species. Between-lake differences in the submerged macrophyte communities might be the cause since ciliate community structure and diversity differ between submerged macrophyte species, even between vegetation stands within the same lake (Mieczan 2007). As a result, the switch of many temperate shallow lakes toward the turbid state due to cultural eutrophication and habitat degradation, a process further intensified by climate change, for instance by changing nutrient dynamics and increased cyanobacterial bloom development (Hansson et al. 2013; Kosten et al. 2012; Özen et al. 2013), may have caused a substantial impoverishment of the regional ciliate diversity in lowland Europe. This merits further study.

At the species level, community structure differed strongly between the two stable states, a phenomenon already observed by Song (2000). Moreover, this difference was associated with the first axis of the species composition PCA, suggesting that it is related to the main variation in the ciliate communities. This was also confirmed by the variation partitioning approach. The alternative stable states in shallow lakes are among the most important structuring factors for all aquatic communities thus far examined (Cottenie et al. 2001; Declerck et al. 2005; van de Meutter et al. 2005). The mechanisms through which the alternative stable states influence ciliate species composition are as yet unclear but may be related to bottom-up (food availability) and/or top-down (predation) factors. For instance, the significantly higher presence of loricate oligotrichs (mainly Codonella cratera and Tintinnopsis cylindrata) in the turbid lakes in comparison with the clear-water lakes (pairwise comparison after Kruskal-Wallis ANOVA, $p=0.004$ ) might be linked to the higher presence of suspended mineral and/or biotic matter used by these species to construct their lorica (Foissner et al. 1999; Henjes \& Assmy 2008). Also the higher food availability in turbid lakes can counteract the higher energy demand (food) for secreting and carrying a lorica, shown to be an effective defense mechanism against copepod grazing in marine environments (Gómez 2007).

The main ciliate species differing in abundance between clear-water and turbid lakes were all eupelagic, and repeating the analyses with only the eupelagic ciliates yielded exactly the same results (data not shown). This shows that the differences between turbid and clear-water ciliate communities were mainly attributable to a turn-over of eupelagic species and not to a higher abundance of macrophyte-associated species in clear-water lakes.

Nutrient level did not have a significant direct effect on ciliate species composition. This suggests that in this type of lakes nutrient status mainly works indirectly by influencing the probability that a lake is in the turbid or the clear-water state. It should be noted, however, that almost all lakes were meso- to hypertrophic. Widening the nutrient range might result in significant direct effects of nutrient status on ciliate community structure. On the other hand, the lack of a direct influence of nutrient status in structuring the planktonic ciliate communities is in line with several other studies documenting that the taxonomic composition of ciliate communities in freshwater lakes hardly shows any change across a broad range in lake trophy (Hwang and Heath 1997; Mathes and Arndt 1994; Pfister et al. 2002).

We focused on the ciliate community structure of the two contrasting stable states that occur in shallow lakes. An additional important variable seems to be lake area, which was included in the variation partitioning after a forward selection RDA revealed its importance. Lake size also had a positive effect on ciliate $\alpha$-diversity measures like species richness (Product-Moment correlation: $r^{2}=0.083, p=0.019$ ) and Shannon Index $\left(r^{2}=0.066, p=0.038\right)$. Especially in anthropogenically influenced lakes (like the lakes in our study), species richness tends to increase with lake size, probably due to the higher spatial variability in larger lakes as was demonstrated for zooplankton, macrophytes, and fish (Dodson 1992; Hoffmann and Dodson 2005; Søndergaard et al. 2005). Lake area might also influence ciliate diversity through differences in zooplankton community structure, since the relative contribution of cladocerans in our dataset tended to be smaller in the larger lakes $\left(r^{2}=0.079, p=0.022\right)$ and a negative association was found between the relative contribution of cladocerans and the ciliate species richness $\left(r^{2}=0.065, p=0.038\right)$ and Shannon Index $\left(r^{2}=0.099, p=0.010\right)$.

In summary, our analysis of the ciliate communities in 66 shallow lakes from lowland Europe showed that (1) ciliate biomass and species composition were best explained by alternative stable state related variables, which allowed identification of several species characteristic of each stable state; (2) no differences in $\alpha$-diversity and functional or higher taxonomical composition could be traced between the ciliate communities of turbid and clear-water lakes, although $\beta$-diversity was higher in clear-water lakes, and (3) no direct effects of nutrient status on ciliate community structure were found, while lake area was identified as an additional structuring variable for the ciliate communities in shallow lakes.

\section{Acknowledgements}

We would like to thank Jon Svendsen, Kim Pedersen, Lissa Skov Hansen, Karina Jensen, Birthe Laustsen, Stig Bech Nielsen (in DK), Vanessa Geenens, Leni Demarest, Koenraad Muylaert, Jochen Vandekerkhove, Luc Denys and Erik J. van Hannen (in BNL) for field, laboratory and analytical assistance. We thank Anne Mette Poulsen for valuable editorial assistance and lake owners and local authorities for lake access. Two anonymous reviewers gave valuable and highly appreciated comments on an earlier version of the manuscript. The study was carried out within the framework of the EU-project BIOMAN (Biodiversity and human impact in European shallow lakes, evk2-ct-1999-00046). EJ and 
TLL were supported by the EU-projects REFRESH (Adaptive strategies to mitigate the impacts of climate change on european freshwater ecosystems, env. 2009.2.1.2.1) and CLEAR (a Villum Kann Rasmussen Foundation, Centre of Excellence project) and EJ also by CIRCE. This paper is dedicated to the first author's newborn daughter Amber.

\section{Appendix A. Supplementary data}

Supplementary material related to this article can be found, in the online version, at http://dx.doi.org/10.1016/j.ejop. 2013.06.001.

\section{References}

Agasild, H., Zingel, P., Karus, K., Kangro, K., Salujõe, J., Nõges, T., 2013. Does metazooplankton regulate the ciliate community in a shallow eutrophic lake? Freshwater Biol. 58, 183-191.

Andersen, T., Hessen, D.O., 1991. Carbon, nitrogen, and phosphorus-content of fresh-water zooplankton. Limnol. Oceanogr. 36, 807-814.

Auer, B., Elzer, U., Arndt, H., 2004. Comparison of pelagic food webs in lakes along a trophic gradient and with seasonal aspects: influence of resource and predation. J. Plankton Res. 26, 697-709.

Azam, F., Fenchel, T., Field, J.G., Gray, J.S., Meyerreil, L.A., Thingstad, F., 1983. The ecological role of water-column microbes in the sea. Mar. Ecol. Prog. Ser. 10, 257-263.

Beaver, J.R., Crisman, T.L., 1982. The trophic response of ciliated protozoans in fresh-water lakes. Limnol. Oceanogr. 27, 246-253.

Beaver, J.R., Crisman, T.L., Bienert, R.W., 1988. Distribution of planktonic ciliates in highly colored sub-tropical lakes - comparison with clearwater ciliate communities and the contribution of myxotrophic taxa to total autotrophic biomass. Freshwater Biol. 20, 51-60.

Blanchet, F.G., Legendre, P., Borcard, D., 2008. Forward selection of explanatory variables. Ecology 89, 2623-2632.

Borcard, D., Legendre, P., Drapeau, P., 1992. Partialling out the spatial component of ecological variation. Ecology 73, 1045-1055.

Bottrell, H.H., Duncan, A., Gliwicz, Z.M., Grygierek, E., Herzig, A., Hillbrichtilkowska, A., Kurasawa, H., Larsson, P., Weglenska, T., 1976. Review of some problems in zooplankton production studies. Norw. J. Zool. 24, 419-456.

Callieri, C., Karjalainen, S.M., Passoni, S., 2002. Grazing by ciliates and heterotrophic nanoflagellates on picocyanobacteria in Lago Maggiore, Italy. J. Plankton Res. 24, 785-796.

Carrias, J.F., Amblard, C., Bourdier, G., 1998. Seasonal dynamics and vertical distribution of planktonic ciliates and their relationship to microbial food resources in the oligomesotrophic Lake Pavin. Arch. Hydrobiol. 143, 227-255.

Clarke, K.R., Gorley, R.N., 2001. PRIMER Version 5. User Manual/Tutorial. PRIMER-E, Plymouth, UK.

Cottenie, K., Nuytten, N., Michels, E., De Meester, L., 2001. Zooplankton community structure and environmental conditions in a set of interconnected ponds. Hydrobiologia 442, 339-350.

Declerck, S., Vandekerkhove, J., Johansson, L., Muylaert, K., Conde-Porcuna, J.M., Van der Gucht, K., Pérez-Martínez, C.,
Lauridsen, T., Schwenk, K., Zwart, G., Rommens, W., LópezRamos, J., Jeppesen, E., Vyverman, W., Brendonck, L., De Meester, L., 2005. Multi-group biodiversity in shallow lakes along gradients of phosphorus and water plant cover. Ecology 86, 1905-1915.

Dodson, S., 1992. Predicting crustacean zooplankton species richness. Limnol. Oceanogr. 37, 848-856.

Dufrene, M., Legendre, P., 1997. Species assemblages and indicator species: the need for a flexible asymmetrical approach. Ecol. Monogr. 67, 345-366.

Foissner, W., Berger, H., Kohmann, F., 1992. Taxonomische und ökologische Revision der Ciliaten des Saprobiensystems - Band II: Peritrichia, Heterotrichida, Odontostomatida. Informationsberichte des Bayer. Landesamtes für Wasserwirtschaft, Heft 5/92, München.

Foissner, W., Berger, H., Kohmann, F., 1994. Taxonomische und ökologische Revision der Ciliaten des Saprobiensystems - Band III: Hymenostomata, Prostomatida, Nassulida. Informationsberichte des Bayer. Landesamtes für Wasserwirtschaft, Heft 1/94, München.

Foissner, W., Berger, H., Schaumburg, J., 1999. Identification and Ecology of Limnetic Plankton Ciliates. Informationsberichte des Bayer. Landesamtes für Wasserwirtschaft, Heft 3/99, München.

Foissner, W., Berger, H., Blatterer, H., Kohmann, F., 1995. Taxonomische und ökologische Revision der Ciliaten des Saprobiensystems - Band IV: Gymnostomatea, Loxodes, Suctoria Informationsberichte des Bayer. Landesamtes für Wasserwirtschaft, Heft 1/95, München.

Foissner, W., Blatterer, H., Berger, H., Kohmann, F., 1991. Taxonomische und ökologische Revision der Ciliaten des Saprobiensystems - Band I: Cyrtophorida, Oligotrichida, Hypotrichia, Colpodea. Informationsberichte des Bayer. Landesamtes für Wasserwirtschaft, Heft 1/91, München.

Fukami, K., Watanabe, A., Fujita, S., Yamaoka, K., Nishijima, T., 1999. Predation on naked protozoan microzooplankton by fish larvae. Mar. Ecol. Prog. Ser. 185, 285-291.

Fyda, J., Warren, A., Wolinska, J., 2005. An investigation of predator-induced defence responses in ciliated protozoa. J. Nat. Hist. 39, 1431-1442.

Galbraith, L.M., Burns, C.W., 2010. Drivers of ciliate and phytoplankton community structure across a range of water bodies in southern New Zealand. J. Plankton Res. 32, 327-339.

Gómez, F., 2007. Trends on the distribution of ciliates in the open Pacific Ocean. Acta Oecol. 32, 188-202.

Grasshoff, K., 1976. Determination of nitrate and nitrite. In: Grasshoff, K. (Ed.), Methods of Seawater Analysis. Verlag Chemie, Weinheim, New York.

Hansson, L.-A., Nicolle, A., Granéli, W., Hallgren, P., Kritzberg, E., Persson, A., Björk, J., Nilsson, P.A., Brönmark, C., 2013. Food-chain length alters community responses to global change in aquatic systems. Nature Clim. Change 3, 228-233.

Henjes, J., Assmy, P., 2008. Particle availability controls agglutination in pelagic tintinnids in the Southern Ocean. Protist 159, 239-250.

Hillebrand, H., Durselen, C.D., Kirschtel, D., Pollingher, U., Zohary, T., 1999. Biovolume calculation for pelagic and benthic microalgae. J. Phycol. 35, 403-424.

Hobbie, J.E., Daley, R., Jasper, S., 1977. Use of nuclepore filters for counting bacteria by fluorescence microscopy. Appl. Environ. Microb. 33, 1225-1230. 
Hoffmann, M.D., Dodson, S.I., 2005. Land use, primary productivity, and lake area as descriptors of zooplankton diversity. Ecology $86,255-261$.

Hwang, S.J., Heath, R.T., 1997. The distribution of protozoa across a trophic gradient, factors controlling their abundance and importance in the plankton food web. J. Plankton Res. 19, 491-518.

Jack, J.D., Gilbert, J.J., 1993. Susceptibilities of different-sized ciliates to direct suppression by small and large cladocerans. Freshwater Biol. 29, 19-29.

Jack, J.D., Gilbert, J.J., 1997. Effects of metazoan predators on ciliates in freshwater plankton communities. J. Eukaryot. Microbiol. 44, 194-199.

Jespersen, A.-M., Christoffersen, K., 1987. Measurements of chlorophyll $a$ from phytoplankton using ethanol as extraction solvent. Arch. Hydrobiol. 109, 445-454.

Jeppesen, E., Søndergaard, Ma., Søndergaard, Mo., Christoffersen, K. (Eds.), 1998. The Structuring Role of Submerged Macrophytes in Lakes. Ecological Studies 131. Springer Verlag, New York.

Jeppesen, E., Søndergaard, M., Søndergaard, M., Christoffersen, K., Theil-Nielsen, J., Jürgens, K., 2002. Cascading trophic interactions in the littoral zone: an enclosure experiment in shallow lake Stigsholm, Denmark. Arch. Hydrobiol. 153, 533-555.

Jerome, C.A., Montagnes, D.J.S., Taylor, F.J.R., 1993. The effect of the quantitative protargol stain and Lugol's and Bouin's fixatives on cell-size - a more accurate estimate of ciliate species biomass. J. Eukaryot. Microbiol. 40, 254-259.

Jürgens, K., 1994. Impact of Daphnia on planktonic microbial food webs - a review. Mar. Microb. Food Webs 8, 295-324.

Jürgens, K., Jeppesen, E., 1998. Cascading effects on microbial food web structure in a dense macrophyte bed. In: Jeppesen, E., Søndergaard, Ma., Søndergaard, Mo., Christoffersen, K. (Eds.), The Structuring Role of Submerged Macrophytes in Lakes. Ecological Studies 131. Springer Verlag, pp. 262-274.

Jürgens, K., Skibbe, O., Jeppesen, E., 1999. Impact of metazooplankton on the composition and population dynamics of planktonic ciliates in a shallow, hypertrophic lake. Aquat. Microb. Ecol. 17, 61-75.

Kahl, A., 1935. Urtiere oder Protozoa I: Wimpertiere oder Ciliata (Infusoria). In: Dahl, F. (Ed.), Die Tierwelt Deutschlands 18, 21, 25, 30. G. Fischer, Jena.

Koroleff, F., 1970. Determination of total phosphorus in natural water by means of the persulphate oxidation. Int. Couns. Explor. Sea (ICES), Interlab. Rep. 3.

Koroleff, F., 1976. Determination of ammonia, phosphorus and silicon. In: Grashoff, K. (Ed.), Methods of Seawater Analysis. Verlag Chemie, Weinheim, New York.

Kosten, S., Huszar, V.L.M., Bécares, E., Costa, L.S., van Donk, E., Hansson, L.-A., Jeppesen, E., Kruk, C., Lacerot, G., Mazzeo, N., De Meester, L., Moss, B., Lürling, M., Nõges, T., Romokk, S., Scheffer, M., 2012. Warmer climates boost cyanobacterial dominance in shallow lakes. Glob. Change Biol. 18, $118-126$.

Laybourn-Parry, J., Rogerson, A., 1993. Seasonal patterns of protozooplankton in Lake Windermere, England. Arch. Hydrobiol. 129, 25-43.

Lepš, J., Šmilauer, P., 2003. Multivariate Analysis of Ecological Data using CANOCO. Cambridge University Press, UK.

MacIsaac, E.A., Stockner, J.G., 1993. Enumeration of phototrophic picoplankton by autofluorescence microscopy. In: Kemp, P.F.,
Sherr, B.F., Sherr, E.B., Cole, J.J. (Eds.), Handbook of Methods in Aquatic Microbial Ecology. Lewis Publishers, Boca Raton, pp. 187-197.

Marchessault, P., Mazumder, A., 1997. Grazer and nutrient impacts on epilimnetic ciliate communities. Limnol. Oceanogr. 42, 893-900.

Mathes, J., Arndt, H., 1994. Biomass and composition of protozooplankton in relation to lake trophy in North German lakes. Mar. Microb. Food Webs 8, 357-375.

Mathes, J., Arndt, H., 1995. Annual cycle of protozooplankton (ciliates, flagellates and sarcodines) in relation to phytozooplankton and metazooplankton in Lake Neumuhler-See (Mecklenburg, Germany). Arch. Hydrobiol. 134, 337-358.

Mayer, J., Dokulil, M.T., Salbrechter, M., Berger, M., Posch, T., Pfister, G., Kirschner, A.K.T., Velimirov, B., Steitz, A., Ulbricht, T., 1997. Seasonal successions and trophic relations between phytoplankton, zooplankton, ciliate and bacteria in a hypertrophic shallow lake in Vienna, Austria. Hydrobiologia 342, 165-174.

McCune, B., Mefford, M.J., 1999. PC-ORD. Multivariate Analysis of Ecological Data, Version 4. MjM Software Design, Gleneden Beach, Oregon, USA.

Menden-Deuer, S., Lessard, E.J., 2000. Carbon to volume relationships for dinoflagellates, diatoms, and other protist plankton. Limnol. Oceanogr. 45, 569-579.

Mieczan, T., 2007. Size spectra and abundance of planktonic ciliates within various habitats in a macrophyte-dominated lake (Eastern Poland). Biologia 62, 189-194.

Montagnes, D.J.S., Lynn, D.H., 1993. A quantitative protargol stain (QPS) for ciliates and other protists. In: Kemp, P.F., Sherr, B.F., Sherr, E.B., Cole, J.J. (Eds.), Handbook of Methods in Aquatic Microbial Ecology. Lewis Publishers, Boca Raton, pp. 229-240.

Moss, B., 1990. Engineering and biological approaches to the restoration from eutrophication of shallow lakes in which aquatic plant communities are important components. Hydrobiologia 200/201, 367-377.

Müller, H., Schlegel, A., 1999. Responses of three freshwater planktonic ciliates with different feeding modes to cryptophyte and diatom prey. Aquat. Microb. Ecol. 17, 49-60.

Muylaert, K., Declerck, S., Geenens, V., Van Wichelen, J., Degans, H., Vandekerkhove, J., Van der Gucht, K., Vloemans, N., Rommens, W., Rejas, D., Urrutia, R., Sabbe, K., Gillis, M., Decleer, K., De Meester, L., Vyverman, W., 2004. Zooplankton, phytoplankton and the microbial food web in two turbid and two clearwater shallow lakes in Belgium. Aquat. Ecol. 37, $137-150$.

Muylaert, K., Pérez-Martínez, C., Sánchez-Castillo, P., Lauridsen, T.L., Vanderstukken, M., Declerck, S., Van der Gucht, K., Zwart, G., Conde-Porcuna, J.-M., Jeppesen, E., De Meester, L., Vyverman, W., 2010. Influence of nutrients and submerged macrophytes on phytoplankton biomass and diversity along a latitudinal gradient in Europe. Hydrobiologia 653, 79-90.

Nakano, S., Ishii, N., Manage, P.M., Kawabata, Z., 1998. Trophic roles of heterotrophic nanoflagellates and ciliates among planktonic organisms in a hypereutrophic pond. Aquat. Microb. Ecol. 16, 153-161.

Ng, H.-T., Marques, D.M.M., Jeppesen, E., Søndergaard, M., 2010. Bacterioplankton in the littoral and pelagic zones of shallow lakes. Hydrobiologia 646, 311-326.

Özen, A., Šorf, M., Trochine, C., Liboriussen, L., Beklioglu, M., Søndergaard, M., Lauridsen, T.L., Johansson, L.S., Jeppesen, E., 2013. Long-term effects of warming and nutrients on 
microbes and other plankton in mesocosms. Freshwater Biol. 58, 483-493.

Peres-Neto, P.R., Legendre, P., Dray, S., Borcard, D., 2006. Variation partitioning of species data matrices: estimation and comparison of fractions. Ecology 87, 2614-2625.

Peretyatko, A., Teissier, S., Symoens, J.J., Triest, L., 2007. Phytoplankton biomass and environmental factors over a gradient of clear to turbid peri-urban ponds. Aquat. Conserv. 17, 584-601.

Pfister, G., Auer, B., Arndt, H., 2002. Pelagic ciliates (Protozoa, Ciliophora) of different brackish and freshwater lakes - a community analysis at the species level. Limnologica 32, 147-168.

Pfister, G., Sonntag, B., Posch, T., 1999. Comparison of a direct live count and an improved quantitative protargol stain (QPS) in determining abundance and cell volumes of pelagic freshwater protozoa. Aquat. Microb. Ecol. 18, 95-103.

Pomeroy, L.R., 1974. The ocean's food web, a changing paradigm. BioScience 24, 499-504.

Porter, K.G., Pace, M.L., Battey, J.F., 1979. Ciliate protozoans as links in freshwater planktonic food-chains. Nature 277, 563-565.

Premke, K., Arndt, H., 2000. Predation on heterotrophic flagellates by protists: food selectivity determined using a live-staining technique. Arch. Hydrobiol. 150, 17-28.

Salbrechter, M., Arndt, H., 1994. The annual cycle of protozooplankton in the alpine, mesotrophic Lake Mondsee (Austria). Mar. Microb. Food Webs 8, 217-234.

Scheffer, M., Carpenter, S., Foley, J.A., Folke, C., Walker, B., 2001. Catastrophic shifts in ecosystems. Nature 413, 591-596.

Scheffer, M., Hosper, S.H., Meijer, M.L., Moss, B., Jeppesen, E., 1993. Alternative equilibria in shallow lakes. Trends Ecol. Evol. 8, 275-279.

Sherr, E.B., Caron, D.A., Sherr, B.F., 1993. Staining of heterotrophic protists for visualisation via epifluorescence microscopy. In: Kemp, P.F., Sherr, B.F., Sherr, E.B., Cole, J.J. (Eds.), Handbook of methods in Aquatic Microbial Ecology. Lewis Publishers, Boca Raton, pp. 213-227.

Skibbe, O., 1994. An improved quantitative protargol stain for ciliates and other planktonic protists. Arch. Hydrobiol. 130, 339-347.

Solórzano, L., Sharp, J.H., 1980. Determination of total dissolved nitrogen in natural waters. Limnol. Oceanogr. 25, 751-754.

Søndergaard, M., Jeppesen, E., Jensen, J.P., 2005. Pond or lake: does it make any difference? Arch. Hydrobiol. 162, 143-165.

Song, B., 2000. A comparative study on planktonic ciliates in two shallow mesotrophic lakes (China): species composition, distribution and quantitative importance. Hydrobiologia 427, 143-153.

Stabell, T., 1996. Ciliate bacterivory in epilimnetic waters. Aquat. Microb. Ecol. 10, 265-272.

ter Braak, C.J.F., Šmilauer, P., 1998. CANOCO Reference Manual and User's Guide to CANOCO for Windows: Software for Canonical Community Ordination. Version 4. Microcomputer Power, Ithaca, New York.

Turley, C.M., Newell, R.C., Robins, D.B., 1986. Survival strategies of 2 small marine ciliates and their role in regulating bacterial community structure under experimental conditions. Mar. Ecol. Prog. Ser. 33, 59-70.
Utermöhl, H., 1958. Zur Vervollkommnung der quantitativen Phytoplankton-Methodik. Mitt. Int. Ver. Theor. Angew. Limnol. 9, 1-38.

van de Meutter, F., Stoks, R., De Meester, L., 2005. The effect of turbidity state and microhabitat on macroinvertebrate assemblages: a pilot study of six shallow lakes. Hydrobiologia 542, 379-390.

Van der Gucht, K., Vandekerckhove, T., Vloemans, N., Cousin, S., Muylaert, K., Sabbe, K., Gillis, M., Declerk, S., De Meester, L., Vyverman, W., 2005. Characterization of bacterial communities in four freshwater lakes differing in nutrient load and food web structure. FEMS Microbiol. Ecol. 53, 205-220.

Van Wichelen, J., Declerck, S., Muylaert, K., Hoste, I., Geenens, V., Vandekerkhove, J., Michels, E., De Pauw, N., Hoffmann, M., De Meester, L., Vyverman, W., 2007. The importance of drawdown and sediment removal for the restoration of the eutrophied shallow Lake Kraenepoel (Belgium). Hydrobiologia 584, 291-303.

Vanormelingen, P., Cottenie, K., Michels, E., Muylaert, K., Vyverman, W., De Meester, L., 2008. The relative importance of dispersal and local processes in structuring phytoplankton communities in a set of highly interconnected ponds. Freshwater Biol. 53, 2170-2183.

Veech, J.A., Crist, T.O., 2009. PARTITION: Software for Hierarchical Partitioning of Species Diversity, Version 3.0. http://www.users.muohio.edu/cristto/partition.htm

Wiackowski, K., Brett, M.T., Goldman, C.R., 1994. Differential effects of zooplankton species on ciliate community structure. Limnol. Oceanogr. 39, 486-492.

Wickham, S.A., 1995. Trophic relations between cyclopoid copepods and ciliated protists - complex interactions link the microbial and classic food webs. Limnol. Oceanogr. 40, 1173-1181.

Wickham, S.A., Gilbert, J.J., 1991. Relative vulnerabilities of natural rotifer and ciliate communities to cladocerans - laboratory and field experiments. Freshwater Biol. 26, 77-86.

Wickham, S.A., Gilbert, J.J., 1993. The comparative importance of competition and predation by Daphnia on ciliated protists. Arch. Hydrobiol. 126, 289-313.

Wu, Q.L., Zwart, G., Wu, J., Kamst-van Agterveld, P., Liu, S., Hahn, M.W., 2007. Submersed macrophytes play a key role in structuring bacterioplankton community composition in the large, shallow, subtropical Taihu Lake, China. Environ. Microbiol. 9, 2765-2774.

Zingel, P., 1999. Pelagic ciliated protozoa in a shallow eutrophic lake: community structure and seasonal dynamics. Arch. Hydrobiol. 146, 495-511.

Zingel, P., Nõges, T., 2008. Protozoan grazing in shallow macrophyte- and plankton lakes. Fund. Appl. Limnol. 171, $15-25$.

Zingel, P., Nõges, T., 2010. Seasonal and annual population dynamics of ciliates in a shallow eutrophic lake. Fund. Appl. Limnol. 176, 133-143.

Zingel, P., Huitu, E., Makela, S., Arvola, L., 2002. The abundance and diversity of planktonic ciliates in 12 boreal lakes of varying trophic state. Arch. Hydrobiol. 155, 315-332. 